\title{
ANADOLU BÖLGE VE YÖRE TIPPLERİ BAĞLAMINDA EĞİSTELİ/BAĞBAŞI (KONYA) FIKRALARI
}

\author{
EĞİSTELİ/BAĞBAŞI (KONYA) JOKES \\ IN THE CONTEXT OF ANATOLIAN REGIONS AND \\ NEIGHBOURHOOD
}

\author{
Aziz AYVA* \\ Muhammed KALAYCI **
}

\begin{abstract}
$\ddot{O} z$
Anlatmaya bağhı Türk halk edebiyatı türleri içerisinde yer alan fikralar; mizahî unsurları, kısa ve yoğun anlatımı, güldürürken düşündüren özelliği ve sade bir dille anlatılmalarıla diğger türlerden kolayca ayrılırlar. Türk fikraları üzerindeki çalışmalar başta Nasreddin Hoca olmak üzere belli başlı tipler üzerinde yoğunlaşmaktadır. Ünü ulusal sınırların dışına taşmış Nasreddin Hoca fikralarının yanında daha dar çevrelerde tanınan yöresel ve bölge tipleri de Türk fikralarının zenginliğinin işareti olarak kabul edilebilir.

Bu bağlamda; Konya'nın Hadim ilçesine bağhı Ĕ̆iste (Bă̆başı) Köyü/Mahallesi insanları üzerine öteden beri anlatılan fikralar da yöresel ve bölge tipleri içerisinde daha önce ele alınmamış bir fikra tipi olarak dikkat çekmektedir. Yöre insanının karşılaştığı olaylar karşısındaki tavrı; mizah, hazırcevaplık ve yöresel unsurlarla birleşince orijinal bir fikra tipini ortaya çıkarmıştır. Makalemizde Ĕ̆giste (Bă̆başı)'den derlenen fikralardan hareketle Ĕğisteli fikra tipinin özellikleri, yörenin coğrafì ve kültürel özellikleriyle tip arasındaki ilişki, fikra tipinin mizah unsurları gibi konular ele alınacak ve yöreden derlenmiş fikralardan örnekler verilecektir.
\end{abstract}

\section{Anahtar Kelimeler}

Halk Edebiyatı, Fıkra, Fıkra Tipi, Eğiste (Bağbaşı), Ĕ̆iste Fıkraları, Mizah.

\begin{abstract}
Included in verbal Turkish folk literature, jokes differ from other types easily in terms of their humorous elements, short and brief descriptions, comic and thought-provoking style as well as their plain language. Studies on Turkish jokes have focused on certain types, especially on those of Nasreddin Hodja. The jokes of Nasreddin Hodja have already become world-famous, and lesserknown and local joke types can be regarded as a mark of richness of Turkish jokes.

In this regard, local and regional jokes which have been told for a long time by the local people in Ĕ̆iste (Bă̆başı) district of Hadim county, Konya, draw attention as they have not been studied before. The local people's reaction to their experiences, together with humor, wittiness and other local
\end{abstract}

\footnotetext{
Yrd. Doç. Dr., Necmettin Erbakan Üniversitesi Sosyal ve Beşeri Bilimler Fakültesi Türk Dili ve Edebiyatı Bölümü Öğretim Üyesi / KONYA / azizayva@hotmail.com

** Yüksek Lisans Öğrencisi, Necmettin Erbakan Üniversitesi Sosyal Bilimler Enstitüsü Türk Dili ve Edebiyatı Ana Bilim Dalı /KONYA / m_kalayci@hotmail.com
} 
elements, has formed this type of joke. In our article, we will deal with jokes from Ĕ̆iste (Bağbaşı) and the properties of these types of jokes, the relation between the type and the geographical and cultural features of the region, humorous elements of the type of joke and samples compiled from the region.

\section{Keywords}

Folk Literature, Jokes, Joke Types, Ĕ̆iste (Bă̆başı), Ĕ̆iste Jokes, Humor. 


\section{GİRIŞ}

Eğiste (Bağbaşı), Konya'nın Hadim ilçesine bağlı bir köydür. 2014 yılında çıkarılan Büyükşehir Yasası ile Hadim'e bağlı bir mahalle durumuna gelmiştir. Bu sebeple fıkralarda kaynak şahısların anlatımlarına bağlı olarak fıkralarda "köy" kavramını kullandık. Konya il merkezine olan uzaklığı $105 \mathrm{~km}$, Hadim ilçe merkezine uzaklığı ise 17 km'dir. Eğiste'nin kuruluş tarihi kesin olarak bilinmemektedir, yöre halkının anlattı̆̆ 1 rivayet ise şöyledir: Bölgeye gelen Yörük aşiretlerinden dört kardeş burayı yurt tutmuşlar, zamanla burada çoğalmışlardır. Bunlar Deveci, Sarı Veliler, Abdurrahman ve Aksaklı lakâbıyla anılan kişilermiş. İşte, Eğiste köyü (mahallesi) bu dört kardeşin neslinden türemiştir. Eğiste adı ile ilgili verilen rivayete göre ise eskiden köyün olduğu yerde "Ĕ̆gri Kilise" adlı bir tapınak varmış. Zamanla bu kelime yöre ağzında bozularak Eğiste adını almıştır.

Eğiste, Osmanlı Devleti zamanında Bozkır'a bağlıdır. Cumhuriyet'in ilk yıllarında Hadim ilçe olmuş ve Eğiste de buraya bağlanmıştır. 1976 yılında köyün ismi Bağbaşı olarak değiştirilmiştir. 1977-2014 yılları arasında kasaba statüsünde yer almış, 2014 yılında çıkarılan Büyükşehir Yasası ile Hadim'e bağlı bir mahalle durumuna gelmiştir. 2016 yılında alınan Belediye Meclisi Kararı ile eski adı Eğiste'ye yeniden kavuşmuştur. (http://www.hadimbagbasi.com.tr, 03.07.2016)

Eğiste'nin halk edebiyatı ve halk kültürü ürünleri denilince ilk akla gelen tür Eğiste Fıkraları'dır. Daha önce, Eğiste fıkralarına değinen bazı yazar ve araştırıcılar olmuştur. Bunlardan ilki Saim Sakaoğlu'dur. Sakaoğlu, "Türk Dünyası Mahallî Tipleriyle Anadolu Fıkra Tipleri Arasındaki Paralellikler" adlı makalesinde Eğiste fıkralarına şu şekilde işaret etmektedir: “Taşı Ürkütmek veya Kafası/Başı Var mıydı? Bu fıkra Kazan'da Ahmet Akay’a, Azerbaycan'da Ayrım Tağı'ya, Anadolu'da Karatepelilere, Hadim ilçesinin Eğiste köylülerine bağlanarak anlatılmaktadır." (Sakaoğlu, 1994: 270).

Eğiste fıkralarından bahseden bir diğer isim de Hadim doğumlu gazeteci-yazar Mustafa Ekmekçi'dir. Ekmekçi, 04.08.1992 tarihli Cumhuriyet gazetesinde yayımlanan "Hadim'den Dikili'ye..." başlıklı yazısında Eğiste fıkralarından şöyle söz eder: "Eğiste deresini geçerken, vaktiyle korkardık. Kimi, tepenin başında iner, karşı tepeye dek yürürdü. Burada kaç kamyon, kaç otobüs uçuruma yuvarlanmış, insancıklar ölmüştü. Eğiste'den gülümseyerek geçtik; Eğistelilerin fıkraları ünlüydü, Nasrettin Hoca fıkraları solda sıfır kalırdı!" (http://www.cumhuriyetarsivi.com, erişim tarihi: 29.05.2016; Ekmekçi, 1992: 12)

Kaynak kişilerimizden 1984 doğumlu Hüseyin Beyhan'ın da birkaç Eğiste fıkrasını yazıya geçirerek 2010 yılında, bir blog sitesinde paylaştığını belirtebiliriz. http://bagbasikasabasi.blogcu.com/egiste-fikrasi, erişim tarihi: 05.06.2016.

Ayrıca Melâhat Ürkmez'in Hadim'in Eğiste mahallesinde yaşanmış bir hayat hikâyesini konu aldığı Ödlek Musa adlı öykü kitabının arka kapağında da bir Eğisteli fıkrası yer almaktadır (Ürkmez, 2014: arka kapak yazısı).

\section{Fıkra Türü ve Fıkra Tipi}

Türk edebiyatında bütün fikralar, halkın yarattığı bir kahramana bağlı olarak anlatılır. Bu kahramana fıkra tipi adı verilir. Fıkraların ana kahramanı bu tipleşme özelliği gösteren kişidir; ancak onun yanı sıra başka yardımcı kahramanlar da yer alır. Bu yardımcı kahramanlara da alt tipler diyebiliriz. 
Dursun Yıldırım, bu konuda şu açıklamayı yapar: "Fıkra tipleri yaşamış kişiler olabileceği gibi, çeşitli zümrelerin, azınlıkların, bölge ve yörelerin, kültürlerin ortak hususiyetlerinin bir araya gelmesinden meydana gelen, fizik ve ruhî portre kazanmış, ortak yapı hususiyetlerini belli bir şahsiyet hâlinde meydana koymuş, kişilik vasfı belirmiş tipler de olabilir. Aslında bütün fıkra-tipleri, öz kişilikleri unutulmuş veya bundan kurtulmuş şahıslar arasından yaratılmıştır. Doğduğu ve yaşadığı cemiyetin ortak yönlerini temsil ettiği ölçüde de tip yayılma, tanınma ve kabul edilme alanını genişletmiştir. Beşerî ve içtimaî unsurları bünyesinde taşıyan fıkra-tipleri, kalıcılık ebedîlik vasfına ulaşmıştır. Tiplerin temsil ettiği şahsiyeti onlara halk kazandırmıştır. Halk, onları görmek istediği kalıplar içinde kabul etmiştir ve bu sebeple de halkın gözü, kulağı, hissiyâtı, aklı, yargı gücü, zekâsı ve sesi olma görevine hak kazanmışlardır. Böyle olunca hiçbir fıkra-tipi, ferdî bir şahsiyet olarak ifade edilemez. Tipin şahsiyeti cemiyetin ve bu cemiyette yaşayan insanların ortak eğilimlerinden şekillendiğine göre, bu tip hiçbir zaman ferdî tip olarak değil, ortak şahsiyeti temsil eden "fıkra-tipi" olarak açıklanabilir (Yıldırım, 1999: 18).

Eğiste fıkralarına geçmeden önce fıkra kavramı hakkında genel bir bilgi vermek yerinde olacaktır. Günümüzde kullanılan fıkra kelimesine denk bir kavram olarak Kaşgarlı Mahmut, Dîvânü Lûgati't-Türk adlı eserinde "köğ" ve "külüt" sözcüklerine yer verir. Kö̆̆, "Bir şehir halkı arasında meydana çıkarak bir sene içerisinde gülünen şey, gülmece" (Atalay, 1941: C. 3, 131) şeklinde açıklanmıştır. Külüt ise, "Halk arasında gülünç olan nesne" (Atalay, 1941: C. 1, 357) olarak tanımlanmıştır.

İslâmiyet öncesinde "külüt" ve "küg" olarak adlandırıldığı düşünülen bu anlatı türüne, "fıkra" nın yanı sıra, geçmiş dönemlerde "latife", "nükte", “hikâye", "mizah", “destan", "kıssa", "masal", "şaka" gibi isimler de verilmiştir. Diğer Türk topluluklarında ise fikra türünü adlandırmak için "latife", "ertegi", "añız", "nükte", "yomak", “değişme", "şorta söz", "küldürgi", "anekdot", "mezek" gibi terimler kullanılmaktadır (Oğuz-Aça vd, 2015: 200).

Dursun Yıldırım, fikrayı şu şekilde açıklamıştır:

"Fıkra, hikâye çekirdeğini hayattan alınmış bir vak'a veya tam bir fikrin teşkil ettiği kısa ve yoğun anlatımlı, beşerî kusurlarla içtimaî ve gündelik hayatta ortaya çıan kötü ve gülünç hadiseleri, çarpıklıkları, zıddiyetleri, eski ve yeni arasındaki çatışmaları sağduyuya dayalı ince bir mizah, hikmetli bir söz, keskin bir istihzâ yoluyla yansıtan; umumiyetle bir fıkra tipine bağlı olarak nesir diliyle yaratılmış, sözlü edebiyatın müstakil şekillerinden ibaret yaygın epik-dram türündeki realist hikâyelerden her birine verilen isimdir." (Yildırım, 1999: 3).

Türk fıkraları üzerine birçok tasnif denemesi yapılmıştır. Türk fıkra tipleri üzerinde bugüne kadar yapılan en kapsamlı tasnif ise Dursun Yıldırım'a aittir. Yıldırım, yaptığı sınıflandırmada fıkra tiplerini yedi gruba ayırmıştır:

1. Ortak şahsiyeti temsil yeteneği kazanan ferdi tipler

a. Türkçenin konuşulduğu coğrafî alan içinde ve dünyada ünü kabul edilen tipler: Nasreddin Hoca.

b. Türk boyları arasında tanınan tipler: İncili Çavuş, Bekrî Mustafa, Esenpulat, Ahmet Akay, Kemîne.

c. Türk boyları arasında halkın veya zümrelerin ortak unsurlarının birleştirilmesinden doğan tipler: Bektaşi, Aldar Köse.

ç. Aydınlar arasından çıkan tipler: Haşmet, Koca Ragıp Paşa, Mîrâli, Nasreddin Tusî, Keçecizâde İzzet Molla.

d. Mahalli tipler.

e. Belli bir devrin kültürü içinde yaratılan tipler: Karagöz. 
2. Zümre tipleri (Mevlevî, Yörük, Terekeme, Tahtac1, Köylü vd.)

3. Azınlık tipleri (Yahudi, Rum)

4. Bölge ve yöre tipleri (Kayserili, Çemişkezekli, Andavallı, Karadenizli, Konyalı vd.)

5. Yabancı fikra tipleri (Behlül, Karakuşî Kadi)

6. Gündelik fikra tipleri

a. Aile fertleriyle alâkalı tipler (Ana-baba, karı-koca, kaynana, baba-çocuk, anne-çocuk vd.)

b. Mariz ve kötü tipler (Deli, hasis, cimri, pinti, kör, topal, sağır, dilsiz, hırsız, dolandırıcı, eşkiya, yankesici vd.)

c. Sanat ve meslekleri temsil eden tipler (Ressam, şair, doktor, avukat, hâkim, bezirgân, bakkal, kasap, molla, asker vd.)

7. Moda tipler (Yıldırım, 1999: 25-32).

Dursun Yıldırım'ın tasnifine baktığımız zaman, makalemizin konusunu teşkil eden Eğiste Fıkraları'nın dördüncü grupta yer alan "bölge ve yöre tipleri" başlı̆̆ı altında ele alınabileceği görülmektedir.

Bölge ve yöre tipleriyle ilgili olarak Dursun Yıldırım şu açıklamayı vermiştir: "Bölge ve yöre tipleri deyince belli bir coğrafya üzerinde yaşayan insanları temsil eden ve bağlı oldukları mekânla isimlenen fikra-tiplerini kastediyoruz. Tipin temel hususiyeti coğrafî bir adla anılması ve adı geçen coğrafya içinde yaşayan insanları temsil etmesidir. Kayserili, Çemişkezekli, Andavallı, Karadenizli, Konyalı gibi isimlerle anılan fıkra-tipleri bu gruba girer." (Yıldırım, 1999: 31).

Anadolu mahallî fıkra tipleri üzerine hazırlanmış en kapsamlı çalışma İbrahim Altunel tarafından hazırlanmış, Anadolu Mahallî Fıkra Tipleri Üzerinde Bir Araştırma (İncelemeler ve Metinler) adlı (1990) doktora çalışmasıdır. Çalışmada, 71 ilimizden 515 fıkra tipine ait 811 fıkra yer almaktadır. Bu dağılımda Konya ili 72 tip ve 179 fıkra ile başta gelmektedir. Çalışmada yer alan Konya mahallî fikra tipleri şöyledir: 1. Tayyip Ağa, 2. Kara Kâmil, 3. Cambaz Deli Osman, 4. Balta Dede, 5. Vahdi Hoca, 6. Gırlı Yakup, 7. Oğlakçı Hacı Hasan, 8. Battal Hacı, 9. Çete (Cemâl), 10. Herif Hüseyin Ağa, 11. Halil'in Ahmet, 12. Mumcu Tahir Efendi, 13. Münir Dede, 14. Ali Ağa'nın İbrahim, 15. Bitcimez'li Ayşe Abla, 16. Deli Kadir Ağa, 17. Hadim Kadısı (Sait Yılmaz), 18. İbrahim Ağabeyli, 19. Kafalı Hâkim, 20. Muhlis Koner Hoca, 21. Mehmet Hoca (Eriş), 22. Mübaşirzade İbrahim Efendi, 23. Noter Fuad, 24. Sıçanlı Ahmet Efendi, 25. Sofu Dayı, 26. Talaş (Mehmet Çiğil), 27. Anız Kıran, 28. Adil Gücüyener, 29. Bitcimez'li Hatice Abla, 30. Canavar (Abdullah), 31. Cepci Hasan Dayı, 32. Daylak Dede, 33. Enver Usta, 34. Hacı Vâcid, 35. Gaffar Ağa'nın Oğlu Cafer, 36. Kaptanzâde, 37. Nalçacı Ali Ağa, 38. Kel Hüseyin, 39. Kel Hasan, 40. Kunduracı Mehmet Ağa, 41. Kara Ali, 42. Hasan Ağa, 43. Hancı Mehmet, 44. İbrahim Efendi, 45. İbrahim Ağa (Zorlu), 46. Noter Fuat'ın Babası, 47. Rifat Ağa (Zorlu), 48. Külahçı Hüseyin Ağa, 49. Salih Efendi Hoca, 50. Uluırmaklı Ahmet, 51. Recep Ağa, 52. Tevfik Ceylanı (Sinemacı), 53. Şeyh Hasan Efendi, 54. Kara Hafızzâde Müfit (Ulusan), 55. Bidon Durmuş, 56. Dikmenzâde Râşit, 57. Ekmekçi Kaptan Dede, 58. Paşa Kâzım, 59. Osman Ağa, 60. Kucur Ahmet Ağa, 61. Kambur Ali Ağa, 62. Manav Mehmet, 63. Panos, 64. Pellümün Mehmet, 65. Zekai Efendi, 66. Cinci Hoca (Duran), 67. Esat Dede, 68. Eğgen Şeyhi Hasan Efendi, 69. Çeşmeci Göşmenoğlu Mustafa, 70. Bödü İbiş, 71. Ak Hoca (Hasan Hüseyin Efendi), 72. Acılar Köylü Hüsnü Hoca (Altunel, 1990: XV-XVII).

Mehmet Çevik de, Abdal Fıkraları Üzerine Bir İnceleme adlı (2016) eserinde; abdallar üzerine anlatılan yöresel ve bölgesel fıkraları tip, motif, şahıs ve mizah ögeleri açısından incelemiştir (Çevik, 2016). 


\section{Eğiste Fıkraları ve Eğisteli Tipi}

Eğiste fıkraları konusunda yukarıda sözünü ettiğimiz çalışmalar oldukça dar kapsamlı olup birkaç örnek fıkranın verilmesinden öteye geçememiştir. Bu konuda yapılmış en kapsamlı çalışma Yrd. Doç. Dr. Selçuk Peker'in danışmanlığında, Muhammed Kalaycı tarafından hazırlanan Anadolu Bölge ve Yöre Tipleri Bağlamında Eğisteli Fıkraları (Metin-İnceleme) adlı yüksek lisans seminer çalışmasıdır. Bu çalışma ile bölgede anlatılan fıkralar ilk kez derli toplu bir şekilde yazıya geçirilmiştir. Çalışmada ayrıca, fıkralar üzerinde incelemeler yapılmış ve yeni bir fıkra tipi edebiyat dünyasına kazandırılmıştır. Çalışmada 27 adet fıkra metnine yer verilmiş ve fıkralar çeşitli yönlerden incelenmiştir. Fıkraları; bölgede 18 Aralık 2015, 20 Mart 2016 ve 6 Mayıs 2016 tarihlerinde gerçekleştirmiş olduğumuz saha araştırmaları sırasında derledik.

Eğisteli tipinin coğrafî bir adla anıldığını ve bu bölgede yaşayan insanları temsil ettiğini söyleyebiliriz. Yani, burada söz konusu olan tek bir ferdin kahramanlaşması değil, bütün köylünün fıkra tipi olarak karşımıza çıkmasıdır. Eğiste fıkralarında gerçek veya hayalî birçok kahraman bulunmaktadır; ancak fıkraların asıl kahramanı Eğisteli tipidir. Buradan hareketle; Eğiste halkının, günlük hayatını, her an fıkralara konu olabilecek şekilde yaşadığını söyleyebiliriz.

Eğisteli tipi fıkralarda genel olarak karşımıza saf, cahil, ahmak vb. şekillerde çıkmaktadır. Bu tür fıkralara edebiyatımızda "alık fikraları" denilmektedir. Ancak Eğisteli tipinin bu alıklığını karakterinin fikralara bir yansıması olarak kabul etmemiz doğru olmaz. Bilakis Eğisteliler akıllı, uyanık kişilerdir. O hâlde bu fıkralar nasıl ortaya çıkmıştır? Bizce bunun iki sebebi olabilir: Birincisi, komşu köylerin kalıp şekildeki fıkraları Eğisteliler üzerine yüklemeleriyle. İkincisi, Eğistelilerin kendilerini alık yerine koyarak geri kalmışlıklarını mizahî bir şekilde hicvetmek istemesiyle. "Mizahta abartma, ironi gibi ince zekâ ürünü yöntemlerin yanı sıra aşağılamalar da vardır. Mizah, düşüncelerin nükte, şaka ve takılmalarla süslenip anlatıldığı bir söz veya yazı çeşididir." (Tuğlacı, 1972: C. 3, 107). "Toplumsal ya da bireysel kusurları, adaletsizlikleri, vb. doğrudan ve dolaylı yoldan eleştiren sanat biçimine mizah adı verilir. Mizahta ironi alaya almaktır, küçümseme vardır, zarafetten uzaklaşabilir. Gülünçleştirme ve ironi bireye ve topluma yöneltilen dolaylı eleştiri biçimidir." (Apaydın, 1993: 21). Erman Artun, Adana Karatepeli Fıkraları adlı makalesinde bu duruma şu şekilde açıklık getirmektedir:

“Bu fıkralarda Türk köylüsünün kendi kendisini ince, nükteli, mizaha konu etmesini görüyoruz. Karatepeli fıkra tipinde eğlenilen, mizaha konu edilen bölge insanının iğneleyen durumunda olduğu sezilir. Karatepelilerin bu fıkraları severek anlatmaları bunu kantlar. Fıkraların yapılarındaki gülme olayını yaratan öğeler göz önünde tutulunca, halkın yaratma gücünden doğan bu estetik biçimlerde ince bir mizah, keskin bir alay ya da hikmetli bir söz mutlaka olur. Toplum yaşantısının, çelişkilerinin düşünce ve davranış farklılıklarından doğan çatışmaların Karatepeli fıkralarına konu edildiğini görüyoruz. Bu fıkraların Karatepeli bölgesi insanının ruh ve düşünce dünyasını anlatmaktan çok bu insanların çeşitli davranışlarındaki aksaklıkları, gariplikleri abartarak anlatma geleneği olarak nitelendirebiliriz. Karatepeliler üzerine anlatılan çeşitli hikâyeleri belli bir yerin, belli bir toplumun ruh ve düşün durumlarını somut bir değerlendirme olarak değil de insanın türlü davranışlarındaki sakatlıkları, aksaklıkları, dil sürçmeleri, alışılmış ölçülerin dışında büyütücü bir aynadan yansıtma saymak doğru olur." (Artun, 1996: 1-3). Pertev Naili Boratav da bu tip fıkralarla ilgili olarak şu açıklamayı yapmıştır: "Dikkat edilirse bu tip hikâyelerin pek çoğunda alay konusu sanılan kişinin alay eden durumunda olduğu fark edilir." (Boratav, 1982: 100).

Bu bilgilerden yola çıkılacak olursa Eğiste fıkralarının ortaya çıkışının ikinci sebebe daha 
yakın olduğu görülür. Yani Eğisteliler kendini alık yerine koymak suretiyle mizah yapmakta ve aslında bölgenin geri kalmışlığını, eğitimsizliği hicvetmektedirler. Böylece sosyal tenkit yapmaktadırlar.

Eğiste fıkralarının ana kahramanı "Eğisteli" tipidir. Bölge ve yöre tipleri içerisinde incelenen bu tip, bir şahsı değil belirli bir bölgenin insanlarını temsil eder. Yani Eğisteli tipi, bütün Eğiste halkını temsil etmektedir. Eğiste fıkralarının şahıs kadrosuna bakıldığında Eğisteli'nin yanı sıra birçok yardımcı kahramanın da olduğu görülmektedir. Bütün bu şahıslar fıkralarda kusurlarıyla, yetenekleriyle, vb. yer almışlardır ve olaylar onlar etrafında cereyan etmiştir.

Eğiste fıkralarının yapı özelliklerini inceleyecek olursak Eğiste fıkralarının gayet açık ve anlaşılır, işlek bir dille anlatıldığını görüyoruz. Fıkralarda bölgenin dil hususiyetleri yoğun bir şekilde görülür. Bu söyleyiş özellikleri ve yöresel kelimelerin imlâsı fıkralarda, özellikle diyaloglarda muhafaza edilmiştir. Konya' da "dağ $\imath^{\prime}$ " diye tabir edilen zümrenin konuşma dilinin özellikleri görülür. Eğiste fıkraları, tarafımızdan yazıya geçirilirken bu dil ve üslûp özellikleri mümkün olduğunca korunmaya çalışılmıştır.

Eğiste fıkralarında, kahramanların üstlendikleri role uygun bir biçimde konuşturulduğu görülmektedir. $\mathrm{Bu}$ durum şahsiyetin halk tarafından daha doğru ve kolay anlaşılması bakımından önemlidir. Fıkralarda genel olarak söz uzatılmamış, mesaj en kısa yoldan verilmeye çalışılmıştır. Ayrıca, Eğiste fıkralarında tahkiyeye pek başvurulmamıştır. Bu nedenle fıkralar genellikle hacim bakımından kısadır. Eğiste fıkralarında birçok cümle türü görülmesine karşın, genel olarak basit yapılı fiil cümlelerinin yoğunluğu göze çarpmaktadır. Fıkralarda çoğunlukla diyalog üslûbu kullanılmış, kahramanlar içinde yaşadığı toplumun günlük konuşma diliyle ve üstlendiği role uygun bir dille konuşturulmuştur. Fıkralar yazıya geçirilirken anlaşılmada güçlük çekilmemesi için, tahkiye bölümlerinde İstanbul Türkçesi kullanılmış; ancak diyalog bölümlerinde bölgenin ağız hususiyetlerinin yansıtılmasına özellikle dikkat edilmiştir. Eğiste fıkralarında genellikle geniş zamanın hikâyesi ve öğrenilen geçmiş zaman kiplerinin kullanıldığı görülmektedir.

Gerek Eğiste fıkralarına, gerekse Türk fıkralarının tamamına bakıldığında zamanın genellikle belirsizlik gösterdiği görülmektedir. Dursun Yıldırım, fıkralarda zaman konusuyla ilgili olarak şunları söylemektedir: "Fıkralarda zaman kategorisi gayri-muayyenlik gösterir. Vak'anın geçtiği zaman pek belli değildir. Türk fıkra kahramanlarından Nasreddin Hoca, İncili Çavuş, Bekrî Mustafa, Kemîne, Mirali ve Bektaşi'ye ait fıkraların bazılarında devre göre yaşamış tarihî şahsiyetler göz önünde bulundurulursa- kısmen zaman mefhumu tespit edilebilir. Fakat bu durum, umumî kaideyi değiştirmez." (Yıldırım, 1999: 9).

Fıkraların kronolojik tarihe kaynaklık edemeyeceğini söylemeliyiz. Bu durum Eğiste Fıkraları için de geçerlidir. Şeref Boyraz bu konuda şöyle demektedir: "Fıkralar, toplumun günlük hayatından kaynaklanmakla beraber tarihî bir vesika değildir. Halk için fıkrada anlatılan olayın ne zaman olduğu değil, ne ve nasıl olduğu önemlidir. Bu yüzden fikralar anlatılırken tarihlerine önem verilmez. Binlerce fıkranın her birinin zamanın tespit etmek ve unutmamak da zaten mümkün değildir. Fıkrada hususî manada bir gün belirtilse bile bunun geniş bir zamanı kapsama hususiyeti vardır. Aksi takdirde fıkraların ömrü sınırlandırılmış olur. Zaman bakımından görülen belirsizlik fıkraların ömründen sınır çizgisini kaldırmış ve onlara geniş zamanın dimağında yaşama ayrıcalığını kazandırmıştır." (Boyraz, 1996: 76).

Yukarıdaki araştırmacıların verdiği bilgilerden hareketle fıkralarda zaman mefhumunu inceleyecek olursak aynı durumun Eğiste fıkraları için de geçerli olduğunu görürüz. Yani Eğiste fıkralarında da zaman mefhumu tam olarak belli değildir. Eğiste fıkralarının bazılarında birden fazla zaman mefhumuna rastlanırken, bazılarında ise zamana dair hiçbir ifade 
bulunmamaktadır. Yine fıkralarda kullanılan zaman kiplerine bakacak olursak, geniş zamanın hikâyesi ve öğrenilen geçmiş zamanın yoğunlukta olduğunu görürüz.

Yıldırım, Türk Edebiyatında Bektaşi Fıkraları adlı eserinde mekânları iki ana gruba ayırmaktadır. Bunlar: 1. Muayyenlik taşıyan mekânlar, 2. Gayri muayyenlik gösteren mekânlar (Yıldırım, 1999: 66). Burada ilk şıktaki mekânları, "coğrafi adlar veya mevki adlarıyla anılmıs, tahsis edilmiş mekânlar" olarak nitelendirir. İkinci şıktaki mekânları ise "birinci kategori içinde yer alan dar veya geniş mekânlar" olarak belirtmektedir. Eğiste Fıkraları'nda da mekan bu sinuflandirmaya uygundur.

Eğiste fikralarında olaylar genellikle Ĕğiste ve çevresinde geçmektedir. Burada anılan mekânların birçoğu, Eğiste'ye komşu olan yerlerdir. Konya sınırları dışında kalan özel mekânlar ise genellikle gurbet motifinin işlendiği veya tatil amaçlı gidilen yerlerdir. Genel mekânlar kategorisine bakılınca da açık yerlerin yoğunluğu dikkat çeker. Açık yerler, genellikle köy ve köy hayatını yansıtan mekânlar olarak karşımıza çıkmaktadır. Eğiste'nin sosyoekonomik ve coğrafî durumunun, fıkralarına da yansıdığını burada açık bir şekilde görmekteyiz.

Hiçbir edebî ürün, içinde oluştuğu toplumdan ayrı düşünülemez. Toplumun duygu ve düşünce dünyası, dönemin siyasal ve ekonomik durumu, halkın yaşayış şekli, kısacası dönemin zihniyeti, bütün edebî ürünlerde kendini hissettirir. Bu açıdan her edebî ürün, topluma ayna tutan birer vesika olarak düşünülmelidir. Mizahî özelliklere sahip olan fıkralar da bu yönüyle incelendiğinde sadece güldürmek, hoşça vakit geçirmek için anlatılan bir tür olmaktan çıkar ve toplumun yaşam tarzını, duygu ve düşüncesini yansıtan eşsiz sanat eserleri oldukları açıça görülür. Konumuz olan Eğiste fıkraları da yöre halkının sosyo-kültürel yapısı hakkında oldukça önemli ipuçları vermektedir.

Eğiste, Akdeniz Bölgesi'nin yüksek kesimlerinde, Toros dağlarının eteklerinde yer almaktadır. Her ne kadar harita üzerinde Akdeniz Bölgesi'nde yer alsa da karasal iklim hüküm sürmektedir. Yazlar sıcak ve kurak, kışlar soğuk ve kar yağışlı geçmektedir. Oldukça dağlık ve engebeli bir arazi yapısına sahiptir, tarımsal arazi son derece azdır. Halk, geçimini genel olarak küçükbaş hayvancllıktan ve meyvecilikten sağlamaktadır. Eğiste'nin bu coğrafî durumu sosyal yapıya büyük oranda yansımış ve Konya'da dağ köylerinin halk edebiyatı ve halk bilimi ürünlerine dolayısıyla da yöreden derlenmiş fıkralara da tesir etmiştir.

Yörenin sosyal yapısının Eğiste fıkraları üzerinde oldukça etkili olduğunu söyleyebiliriz. Özellikle eğitimsizlik, halkın cahilliği, köylü-kentli çatışması, halkın çektiği geçim sıkıntısı Eğiste fıkralarında en sık görülen unsurlardır. Örneğin; "Arabanın Vitesi" adlı fıkrada otomobille ilk kez karşılaşan Eğisteli, oğlu oynaya oynaya bozacak diye vitesi yerinden söker. Yine "Kamyon Kasası" adlı fıkramızda gurbet yollarına düşen Eğisteliler, sökük hâlde duran kasaya binip Aydın'a gitme umuduyla saatlerce beklerler. "Keme" adlı fikramızda saatin tıkırtılarını fare sesi sanan Eğisteli, saati paramparça eder. "Minare Tohumu" adlı fıkrada uyanık bir Kayserili tarafından kandırılan Eğistelinin saflığı anlatılır. "Nörün Ali A ̆ğa" fıkrasında dinî bilgilerden yoksun olan Eğisteli, hocanın hâlini, hatırını sorduğunu sanarak sevinir. Buna benzer örnekleri artırmak mümkündür. Eğisteli Bekçi, İlahana, Kaya Ürkütmek, Köpeğg Şart Ettirmek, Kunduza Mektup, Saklambaç, Salimen Salınır Gelirse, Tarlaya Tuz Ekmek fıkralarında eğitimsizliğin, cahilliğin, garibanlığın izlerini görürüz.

İçinde yaşanılan bölge toplumun ekonomik faaliyetlerine, sosyal yapısına, giyim-kuşamına hatta mizacına, duygu ve düşünce dünyasına bile tesir eder. Eğiste fıkralarında bu yansımalar sıkça karşımıza çıkar. Bölgenin dağlık ve engebeli olduğunu yukarıda söylemiştik. Buna bağlı olarak halk geçimini genellikle meyvecilikten sağlamaktadır. Burada en yaygın tarımsal faaliyet bağcllık yani üzüm yetiştiriciliğidir. Üretilen üzümler yaş, kuru veya pekmez yapılmak 
suretiyle satılır, özellikle Eğiste Pekmezi Konya'da oldukça meşhurdur. Halkın temel geçim kaynaklarından olan üzüm ve pekmezin, Eğiste fıkralarında da sıkça yer bulduğu görülmektedir. Örnek vermek gerekirse; "Aşağı Bağın Armudu" fıkrasında Konya'ya pekmez satmaya giden bir Eğistelinin uyanıklığı anlatılır. "Ĕ̆gisteli Bekçi" adlı fıkramızda Bolatlılar, hırsızlardan bağlarını korumak için bir Eğisteli'yi bekçi olarak tutarlar. "İsmariş̧" adlı fıkramızda Eğisteli Mehmet Ağa karısıyla birlikte dama üzüm sermektedir. Son olarak "Keme" adlı fıkrada da Eğisteli'nin bağ çapası yaptığından söz edilir.

Yine bölgenin temel geçim kaynaklarından olması hasebiyle hayvancılık da fikralarda karşımıza çımaktadır. "Bir Çift Laf" adlı fıkramızda hayvanlarını çobanın önüne katıp dedikoduya dalan kadınlardan ve keşşik kültüründen bahsedilir. "Kalbur Kasnak" adlı fıkrada hayvanlara yem vermek için ahıra giren Eğistelinin, kalbur ve kasnakların saldırısına maruz kalışı (!) anlatılır. "Miyil Miyil Bakar" adlı fıkramız, hayvanlarına bakmak için ahıra giden Eğisteli imamın canavarla göz göze gelmesi olayı üzerine kurulmuştur.

Bölgede tarımsal faaliyetlerde makine kullanımı pek mümkün değildir. Zaten köylünün ekonomik durumu da pek iyi olmadığından gerek tarımsal faaliyetlerde, gerekse taşımacılıkta eşek kullanılmaktadır. Bu durumun fikralarda kendine bolca yer bulduğunu görüyoruz. "Aşağr Bağın Armudu" fıkrasında Konya'ya pekmez satmaya giden Eğistelinin, bidonları eşeğe yüklediğini görürüz. "Eşeğe Saman Veremez" adlı fıkramızda eşeğe saman bile vermekten üşenen bir Eğisteli'nin kurnazlığı anlatılır. "Geldiğin Dağlara Merkepsiz Çıkılmaz" fıkrasında kültürel yozlaşma konusuna vurgu yapılır. "Ya Kaymakam Ya Emniyet Müdürü" fikrasında ise çerçicilik yapan Eğisteli Veli Dayı'nın malları eşeğin sırtına yükleyip köy köy, kasaba kasaba gezdiğinden söz edilir.

Geçim kaynaklarının sınırlı oluşu Eğiste halkını, köyden kente göç etmeye zorlamıştır. Köydeki "irezil" hayattan kurtulmak isteyen Eğisteli delikanlılar, gurbet ellerin yolunu tutmuşlar, genç kızlar da şehirli biriyle evlenmenin hayâlini kurmuşlardır. Öyle ki şehirde oturmak, evliliklerde öne sürülen başlıca şartlar arasına girmiştir. Bu durumun da Eğiste fıkralarına yansıdığını görüyoruz. Fıkralarda köyden kente göçün yarattığı sorunlar, Eğisteliler'in şehre ayak uyduramayışı ve kültür yozlaşması konuları işlenmiştir. Örneğin; "Geldiğin Dağlara Merkepsiz Çıkılmaz" fıkrasında aile, kızımız şehre gelin olacak diye hiç nazlanmadan kızı verir ve şehre yerleşen kız zamanla, içinden çıktığı toplumu beğenmez bir hâle gelir. "İlahana" adlı fıkramızda Ali, Veli, Deli adlarında Eğisteli üç arkadaşın geçim sıkıntısından kurtulmak için İstanbul yollarına düşmeleri ve buradaki trajikomik hâlleri anlatılır. "Kamyon Kasası" adlı fıkramız da gurbet temasını işlemektedir. Bu fıkrada da yine üç Eğistelinin Aydın yollarını tuttuğunu görürüz.

Konum olarak Konya ile Alanya arasında yer alan Eğiste, yörüklerin uğrak noktalarından biridir. Özellikle yaz mevsiminde sürüsünü önüne katan yörükler, keçilerini otlatmak için Torosların kuzeyine geçmekte Bozkır, Hadim, Taşkent civarındaki yaylalarında konaklamaktadırlar. Her ne kadar eski canlılığını yitirmiş olsa da bu gelenek günümüzde de devam etmektedir. Bu bölgede hâlâ elinde asası, ayaklarında naylon ayakkabısı, başında oyalı yazması, önünde keçileriyle yörükleri görmek mümkündür. Yörüklerle olan bu münasebetlerini Eğisteliler, fıkralarına da yansıtmışlardır. "Beni Arayan Alanya'da Bulsun" fıkrasında yörüklerin Eğiste'de konakladıkları dile getirilir. Ayrıca yörük kervanlarından ve develerinin Eğisteliler'in ilgisini çekişinden söz edilir. "İsmariş" adlı fıkramızda da yörüklerle olan ticarî münasebetler ve bir yörük kızı ısmarlama olayı anlatılır. Bu fıkrada karşımıza çıkan sipariş yoluyla, evleneceği kişiyi dahi görmeden bir yörük kızının getirilmesi olayı ilginçtir. Belki de Eğisteliler bu fıkrada, kendilerinin yörüklerden daha rahat bir yaşama sahip 
olduklarını, bu nedenle yörük kızlarının kendilerini almaya can attıklarını anlatmak istemiş olabilirler. Bu durum günümüzde de Doğu bölgemizde görülmekte, aileler kızlarına daha iyi bir gelecek sunma adına, onları Batı bölgesine gelin etmek istemektedirler.

Eğiste fıkralarında sosyal yapı konusuyla ilgili son olarak köyler arası çekişme ve mücadeleden söz etmek istiyoruz. Hemen hemen tüm yurtta birbirine komşu olan köylerin birbirlerini pek sevmedikleri, birbirlerini çekemedikleri, husumet güttükleri hatta zaman zaman büyük kavgalar ettikleri bilinmektedir. Mesela Osmaniye'nin Kadirli ve Kozan ilçeleri arasındaki husumet oldukça meşhurdur. Hatta aralarını düzeltmek için "Kadirli-Kozan Kardeşlik Köprüsü" adıyla bir de köprü yaptırılmıştır. Konya'da da Söğütlüler ve Asarlıklılar arasındaki mücadeleler oldukça büyük kavgalara neden olmuştur. Bu türden mücadeleleri Eğiste-Bolat arasında da görmekteyiz. Ancak yukarıdakilerden farklı olarak Eğisteliler ve Bolatlılar kavga, dövüş yoluna gitmemişler, mücadelelerini edebî bir alanda yaparak fıkralara taşımışlardır. Gerek fıkralarda gerekse günlük yaşamda bu mücadele, belirgin bir şekilde hissedilir. "Ĕğisteli Bekçi" fıkrasında Bolatlılar, bir Eğisteliyi bağlarına bekçi olarak tutarlar. Eğisteli bekçi, yakaladığı hırsızın ayaklarını bağlar; ancak ellerini bağlamaz. Bu fıkrada Eğistelilerin saflığıyla dalga geçilir. "Salimen Salınır Gelirse" adlı fıkrada önce bir aile sonra bütün Eğiste halkı ağaçta asılı duran balta düşüp çocukları öldürecek diye feryat figan ederler; sesler Bolat'tan duyulur ve Bolatlı birinin baltayı ağaçtan indirmesiyle sorun çözülür. Yine bu fıkrada da Eğistelilerin saflığı, ahmaklığı üzerinde durulmuştur. Burada şunu belirtmekte de fayda görüyoruz. Fıkralar her ne kadar Eğistelilerle dalga geçmek amacıyla Bolatlılar tarafından uydurulmuş gibi görünse de derlemeler esnasında bu fıkraların Bolat'ta bilinmediğini gördük. Hâl böyle olunca bu fıkralarda Eğistelilerin aslında kendilerini saf yerine koyarak kendi kendileriyle dalga geçtikleri ve bir yandan da eğitimsizliğe, cahilliğe göndermede bulundukları görülür. "Yaşa Bolatlı" adlı fıkrada ise kozlar Eğisteli'nin elindedir. Bu fıkrada Eğisteli, Bolatlı'nın hareketlerini ayıplar ve onu hafif-meşrep biri olarak gösterir. Bolatlllarla olan mücadele kadar açık olmasa da "Bi Kıçın Dönsün Bi Başın" fıkrasında da Armutlu köyü ile olan çekişme hissedilir. Bu fıkrada Eğistelinin vurduğu keklik yaralı bir şekilde Armutlu tarafına kaçar. Eğisteli, kaçan kekliğin ardından söylediği sözlerle, bir yandan kekliğe acı yaparken diğer yandan da Armutluların damak tadını eleştirmiş olur.

Elimizdeki fıkralara baktı̆̆ımız zaman, tüm köyü temsil eden fıkra tipi, "Eğisteli"dir. Eğisteli, bu fıkraların birçoğunun baş kahramanı ve ortak şahsiyeti temsil eden fıkra tipidir. Eğiste fıkralarında, Eğisteli'nin dışında Mehmet Ağa, Hacı Ali'nin Ahmet, Ali Ağa, Veli Dayı gibi başka kahramanlar da vardır. Ancak, sayıca az olan bu kahramanlar, tipleşme eğiliminde değildir ve hepsinin ortak noktası yine Eğisteli olmalarıdır. Fıkralarda da isimlerinin başına Eğisteli sıfatı getirilerek anılırlar. Yani fıkralarda, şahısların isimlerinden ziyade memleketlerine vurgu yapılmaya çalışılır. Biz, bu nedenle derlediğimiz bütün fıkraların fıkra tipini Eğisteli olarak kabul ettik ve tipin özelliklerini buna göre vermeye çalıştık.

\section{Eğiste Fıkralarının Mizah Unsurları}

\section{Ahmak-Alik}

Arapça bir sıfat olan ahmak kelimesini, Türk Dil Kurumu şu şekilde açılar: "Aklını gereği gibi kullanamayan, bön, budala, aptal." Eğiste fıkralarının büyük bir bölümünde Eğisteli tipi, ahmak bir karakter olarak karşımıza çıkar. Ancak bu ahmaklığın temelinde geri kalmışlığın yani eğitimsizliğin yattı̆̆ 1 görülür. Aslında Eğisteli, kendini ahmak yerine koymak suretiyle, alttan alta bu durumu eleştirmektedir.

"Arabanın Vitesi" adlı fikrada Eğisteli'nin otomobille ilk karşılaşması ve bu durumda gösterdiği tepki anlatılır. "Eğisteli Bekçi" adlı fıkrada Eğisteli Bekçi, ayaklarını bağladığı hırsızın 
ellerini serbest bırakır; ancak hırsız da Eğisteli olduğundan ayaklarını çözüp kaçmayı düşünemez. "Kamyon Kasası" adlı fıkramızda Eğisteliler, Aydın'a gidecek diye sökük kamyon kasasında saatlerce beklerler. "Kaya Ürkütmek" adlı fıkra, Eğisteli tipinin ahmaklığını gösteren güzel örneklerden biridir. Bu fıkrada, gerek Eğisteliler'in kayayı ortadan kaldırmak için buldukları çözüm yolu, gerekse kaybolan kafayı arayışları bir hayli komiktir. "Keme" adlı fıkrada, ömründe ilk kez bir saat sahibi olan Eğisteli'nin, saatin tıkırtılarını fare sesi sanışı anlatılır. "Köpeğge Şart Ettirmek" adlı fıkrada Eğisteli, köpeğe saldırmayacağı üzerine yemin ettirir. Eğisteli Hacı Ali'nin Ahmet, "Kunduza Mektup" adlı fıkrada, tuzağını geri getirmesi için kunduza yalvarır, yakarır. "Minare Tohumu" adlı fikra da uyanık bir Kayserili tarafından aldatılan Eğisteli'nin hikâyesi anlatılır. "Nörün Ali Ağg" adlı fıkra, dinî bilgilerden yoksun olan Eğisteli'nin, imamın sözlerini yanlış anlaması üzerine kuruludur. "Saklambaç" adlı fıkramızda, kolayca bulunmak istemeyen Eğisteli, uzak bir yere saklanır ve günlerce orada bekler. İşin daha ilginç yanı, oyunda ebe olan Eğisteli de günlerce arkadaşını arar. "Salimen Salınır Gelirse" adlı fıkrada Eğisteliler, doğmamış çocuğa don biçip ölümüne ağlarlar. Eğisteli tipinin ahmaklığını anlatan en güzel fıkralardan biri "Tarlaya Tuz Ekmek"tir. Eğiste fikraları içerisinde en meşhuru budur. Günümüzde de bölgede Eğisteliler, "tarlaya tuz ekenler" olarak adlandırılır. Bu fıkra, Eğistelilerin tuz ihtiyacını karşılamak için bulduğu çözüm yolunu ve giriştikleri mücadeleyi konu alır.

\section{Mikro Milliyetçi}

Fıkralarda Eğisteli tipi, vatanına, milletine oldukça bağlı bir karakter olarak görülür. Aynı zamanda Eğisteli, memleketçilik duygusuna da sahiptir. Kendi köyünü ve köylüsünü üstün tutmaya, komşu köylerin insanlarını da alttan alta küçük görmeye, eleştirmeye çalışır. "Bi Kıçın Dönsün Bi Başın" adlı fıkrada Eğisteli, yaralı kekliğin ardından; "Hadi get bakalım. Benim elime geçeydin seni gözelce haşlayıp sade yağında gızartıp pilavın üstüne koyacaktım. Şimdi get, Armutlulular seni su dolu çencerenin içine goysunlar da darhana aşının içinde bi gıçı dönsün, bi başın." derken aslında kendilerinin damak tadını övmekte, Armutlu halkının damak tadını ise yermekte ve beğenmemektedir. "Yaşa Bolatlı" adlı fıkra, Eğistelinin mikro milliyetçi tutumunu göstermesi bakımından kayda değer. Bu fıkrada Eğisteli, Bolatlı'nın hareketlerinden rahatsız olur ve onun Eğisteli olmadığını ifşa eder. Bu şekilde kendi köyünü ağırbaşlı, vakur gösterirken Bolatılıarı da gevşek, hafif-meşrep olarak yansıtmaya çalışır.

\section{Kivrak Zekâlı-Uyanık}

Yukarıda dile getirilen ahmak tipinin aksine, bazı fıkralarda da Eğisteli'nin kıvrak zekâsı ve uyanıklığı konu edilmiştir. Bu durum ilk bakışta tezat teşkil ediyor gibi görünse de Eğisteli tipinin ahmak olmadığını, bilakis kendini alay konusu ederek mizah yaptığını göstermesi bakımından dikkate değerdir. Sayıca az da olsa, bazı fıkralar Eğisteli tipinin bu özelliği üzerine kuruludur. "Aşă̆ı Bă̆ın Armudu" fıkrasında Eğisteli, içinde bulunduğu zor durumdan kıvrak zekâsı sayesinde kurtulur ve pekmezin tamamını satmayı başarır. Yine "Yaşa Bolatı" adlı fıkrada Eğisteli, kıvrak zekâsıyla köyünün adının lekelenmesini önler. "Eşeğe Saman Veremez" adlı fıkra da Eğisteli tipinin uyanıklığı üzerine kurulmuştur. Bu fıkrada Eğisteli, krizi fırsata dönüştürmenin yollarını aramaktadır. Hastalık nedeniyle birçok nimetten uzak kalacak olan Eğisteli, köy işlerinden de kaytarmanın peşindedir. 


\section{Korkak}

Eğisteli tipinin korkaklığı iki fıkrada söz konusu edilmiştir. Bunlardan birincisi, "Miyil Miyil Bakar" adlı fıkramızdır. Bu fıkrada, Eğisteli imamın bir kurtla karşılaşması sonucu yaşadığı korkuyu bir türlü üzerinden atamayışı anlatılır. İkincisi ise, "Sensin Kalıpsız" adlı fıkradır. Bu fıkra da Eğistelinin korkaklığı daha açık bir şekilde görülür. Eğisteli, bu fıkrada kendine hakaret eden ayakkabıcıya korkusundan bir karşılık veremez. Konya'dan yeterince uzaklaştığına kanaat getirince karşılık verir ve intikamını alır. Kılıbıklık olarak adlandırılan eş korkusuna da bu başlık altında yer verelim. "İsmariş" adlı fıkrada Eğisteli Mehmet Ağa, karısının korkusundan verdiği siparişi alamaz ve emaneten köylüsüne bırakır.

\section{5. İnatçı}

Eğistelinin inatçı kişiliğini "Köpeğe Şart Ettirmek" adlı fıkrada görüyoruz. Bu fıkrada, Eğisteli'nin gerek köpeği satın almak için gösterdiği çaba, gerekse köpeğe yemin ettirmek için kullandığı yöntem onun inatçı yönünü gözler önüne serer.

\section{Hazırcevap}

Yukarıda işlediğimiz kıvrak zekâlılığın bir sonucu olarak bazı fıkralarda da Eğisteli tipini hazırcevap olarak görürüz. "Geldiğin Dağlara Merkepsiz Çıkılmaz" adlı fıkrada Mehmet Emmi, şehirli oldum diye kendisini büyük gören köylüsüne, öyle bir laf eder ki ona nereden geldiğini hatırlatır. "Ya Kaymakam Ya Emniyet Müdürü" adlı fıkrada da Eğisteli Veli Dayı, kendisini küçük düşürüp alaya almak isteyen kaymakama, altından kalkamayacağı bir karşılık verir. Bu fıkralarda Eğisteli'nin, tabiri caizse, taşı gediğine oturttuğu görülür.

\section{Sinirli-Efe}

Konya'da dağ yöresinin insanları için, "havası sert, suyu sert, insanı mert" denildiğini daha önce de söylemiştik. Belki de havasından, suyundan olsa gerek bu bölgenin insanının aynı zamanda bir de sinirli yönü vardır. Ancak bu sinirlilik saman alevi gibidir, hemen geçer, kindarlık yoktur. Bu bölgede sinirli insanlar için "efe" tabiri kullanılır. "Kalbur Kasnak" adlı fıkrada Eğisteli, kendine çarpıp duran kasnağa sinirlenir ve tabancasını çıarıp ne kadar kalbur, kasnak varsa hepsine meydan okur.

\section{Cimri}

Eğiste'nin sosyo-ekonomik durumundan önceki bölümlerde bahsetmiştik. Bölge dağlık ve engebeli olduğundan tarıma elverişli arazi oldukça azdır. Bu durum köylülere iki seçenek sunar: Birincisi, köyde kalıp kıt kanaat geçinmek; ikincisi gurbet yollarına düşmek. "Illahana" fıkrası, ikinci seçeneği seçen Eğisteli üç arkadaş üzerine anlatılır. Bu fıkrada, garibanlığ 1 iliklerine kadar hisseden Eğisteliler'in, armudun sapını, üzümün çöpünü hesap edecek kadar pintileşmeleri anlatılır.

\section{Dedikoducu-Geveze}

Bu karakter, Eğisteli iki kadın tipinde görülür. "Bir Çift Laf" adlı fıkramızda Eğisteli kadınlar, sabahtan akşama kadar gevezelik edip dedikodu yaparlar; ancak yine de konuşacakları yarıda kaldı diye çobana çıkışırlar. Eğisteli bu kadın tiplerini, Dede Korkut Kitabı'nın giriş bölümünde zikredilen dört kadın tipinden "tolduran top"a benzetmiştir. Burada "kov kovladı" şeklinde geçen dedikodu kelimesinin bu fıkrada "gov govlamak" şeklinde 
yaşadığını görüyoruz.

\section{Cahil Cesaretli}

Cehalet ve ahmaklık insana olmayacak işler yaptırır. Cahil insan, işin sonucunu pek hesap edemediği için cesur davranır ve kendini tehlikenin içine atar. "Kaya Ürkütmek" adlı fıkrada, bu türden bir cesaret örneği vardır. Köyü kayanın tehdidinden kurtarmaya çalışan Eğisteliler, kayayı korkutup kaçırmayı düşünürler. Bu fikrin de içlerinde en akıllı olan tarafından verilmesi oldukça manidardır. Bu fıkrada cesur(!) Eğisteli, kayayı korkutayım derken kafasından olur ve cesaretinin bedelini canıyla öder.

\section{1. Şakacı-Muzip}

Arapça bir sıfat olan muzip kelimesini Türk Dil Kurumu, "takılgan" şeklinde açklar. Bölgede muzip kelimesi, şakacı anlamında sıkça kullanıldığından her iki kelimeyi birlikte vermeyi uygun gördük. Eğisteliler oldukça şakacı, yani muzip insanlardır. Fıkralarının yanı sıra günlük hayatlarında da bu durum çok rahat görülür. Bir örnek olarak, "Beni Arayan Alanya'da Bulsun" adlı fıkrada, Hisaburuk lakaplı muzip bir Eğisteli, arkadaşı Kamber'i deveye bindirip belindeki kuşakla devenin kuyruğuna bir köpek bağlar. Köpekten korkan deve, hızla koşmaya başlar. Bu fıkrada Hisaburuk'un Kamber'e kötü bir şaka yaptığı görülür.

\section{SONUÇ}

Sonuç olarak şunları söyleyebiliriz: Eğiste fıkraları, fıkra tasnifine göre "bölge ve yöre tipleri" grubuna girer. Eğiste fıkralarının başkahramanı, Eğisteli tipidir. Fıkralarda başka şahıslar da bulunmakla birlikte, olaylar hep "Eğisteli" etrafında cereyan eder. Fikralardaki diğer şahısların da adı değil memleketleri ön plana çıkarılır. Eğisteli tipi, fıkralarda birçok şekilde karşımıza çıkar; ancak genellikle görünürde ahmak bir karakteri canlandırır. Aslında bu görünenin altında derin bir sosyal tenkit anlayışı yatmaktadır. Şöyle ki, Eğisteli tipinin bu ahmaklığını, Eğistelilerin günlük hayattaki davranışlarının fıkralarına bir yansıması olarak görmek doğru değildir. Aslında Eğisteli, kendini ahmak yerine koyarak eğitimsizliği eleştirmekte ve alay edilen konumundayken fark ettirmeden alay etmektedir. Geri kalmışlığın, maddî yoksunluğun acı bir şekilde hissedildiği Eğiste'de, anlatılan bu fıkraların fonksiyonlarından biri de halkı bu acı gerçeklerden bir nebze olsun uzaklaştırarak yüzünde bir tebessüm oluşturmaktır. Diğer yandan Eğisteli tipinin kendini ahmak, cahil, saf yerine koymak suretiyle bölgenin geri kalmışlığını, eğitimin yetersizliğini hicvetmek istediği de açıkça görülmektedir.

Eğiste fıkraları, Konya'da "dağlı" olarak adlandırılan bölge insanlarının ağız özelliklerini taşır. Fıkralar yazıya geçirilirken bu yapının bozulmamasına dikkat edilmiş ve özellikle fıkraların diyalog bölümlerinde ağız özellikleri yansıtılmaya çalışılmıştır. Eğiste fıkralarının dili, oldukça açık ve sadedir. Fıkralarda tahkiye yoluna pek gidilmemiş, söylenmek istenen kısa ve net bir şekilde anlatılmıştır.

Eğiste fıkralarına bakarak, bölgenin sosyal ve kültürel dokusuna ilişkin birçok bilgiye ulaşabiliriz. Fıkralarda bölgenin sosyal yapısından, ekonomik kaynaklarından, insanların hayat tarzlarından, duygu ve düşünce dünyalarından izler görülür. Eğiste fıkraları ayrıca, bölgenin folklorik özelliklerine dair de birçok malzeme ihtiva eder.

Eğiste fıkralarında olağanüstü olaylar ve kahramanlar görülmez. Yani fıkralar gerçek hayatta karşılaşılabilecek türdendir, hayatın içinden bir kesittir. Zaten fıkraların bir kısmı da 
yaşanmışlıklara dayanır. Anı olarak anlatılan bu olaylar, zamanla fıkralaşma temayülü göstermiştir.

Eğiste fıkralarında, zaman unsuru genel olarak belirsizdir. Fıkralar eskiden, evvel zamanda gibi kalıp zaman ifadeleriyle başlar. Eğiste fıkralarında mekân genellikle Eğiste'dir. Bunun dışında çevre köylerin ve gurbet motifine bağlı olarak bazı illerin de adının geçtiği görülür.

Eğiste fıkralarının ortaya çıkışı ile ilgili olarak da iki kanaat belirtebiliriz. Bunlardan birincisi, civar köylerin husumete bağlı olarak, kalıp hâldeki bazı fıkraları Eğistelilere yüklemesi. İkincisi ise, Eğistelilerin kendi kendilerini mizah konusu etmek suretiyle, bölgenin geri kalmışlı̆̆ını eleştirmek istemesidir. Bu kanaatlerden ikincisi bize göre daha ağır basmaktadır. Bu fıkraları Eğistelilerin severek anlatmaları, civar köylerde bu fıkraların pek bilinmemesi ve fıkralarda genellikle eğitimsizliğin, geri kalmışlığın söz konusu edilmesi bizi ikinci kanaate yaklaştıran sebeplerden bazılarıdır. 


\section{KAYNAKÇA}

ALTUNEL, İbrahim (1990), Anadolu Mahallî Fıkra Tipleri Üzerinde Bir Araştırma (İnceleme ve Metinler), (Yayımlanmamış Doktora Tezi), Selçuk Üniversitesi Sosyal Bilimler Enstitüsü, Konya. APAYDIN, Mustafa (1993), Türk Hiciv Edebiyatında Ziya Paşa, (Yayımlanmamış Doktora Tezi), Çukurova Üniversitesi Sosyal Bilimler Enstitüsü, Adana. ARTUN, Erman (1996), “Adana Karatepeli Fıkraları”, Adana.

BORATAV, Pertev Naili (1982), 100 Soruda Türk Halk Edebiyatı, Gerçek Yayınları, İstanbul.

BOYRAZ, Şeref (1996), “Nasreddin Hoca Fıkralarında Zaman, Mekân ve Şahıslar”, Nasreddin Hoca'ya Armağan, (hzl. M. Sabri Koz), İstanbul.

ÇEVIK, Mehmet (2016), Abdal Fıkraları Üzerine Bir İnceleme, Ankara, Ürün Yayınları.

EKMEKÇİ, Mustafa (1992), “Hadim'den Dikili'ye...”, 04.08.1992 tarihli Cumhuriyet Gazetesi, s. 12.

Dîvânü Lûgati't Türk (1941), (hzl. Besim ATALAY), Ankara.

KALAYCI, Muhammed, (2016) Anadolu Bölge ve Yöre Tipleri Bağlamında Eğisteli Fıkraları (Metinİnceleme), Konya 2016, Necmettin Erbakan Üniversitesi Sosyal Bilimler Enstitüsü Yayımlanmamış Yüksek Lisan Semineri, (Dnş: Yrd. Doç. Dr. Selçuk PEKER), 95 s.

OĞUZ, Öcal-AÇA, Mehmet, vd. (2015), Türk Halk Edebiyatı El Kitabı, Grafiker Yayınları, s. 200-207, Ankara.

SAKAOĞLU, Saim (1994), “Türk Dünyası Mahallî Tipleriyle Anadolu Fıkra Tipleri Arasındaki Paralellikler", Selçuk Üniversitesi Fen-Edebiyat Fakültesi Edebiyat Dergisi, S. 9-10, Konya. (16 Aralık 1993 tarihinde Türk Dil Kurumu'nda verilen konferansın metnidir.)

TUĞLACI, Pars (1972), “Mizah”, Okyanus Ansiklopedik Sözlük, C. III, s. 107, İstanbul.

ÜRKMEZ, Melâhat (2014), Ödlek Musa, Gençlik Kitabevi Yayınları, Konya.

YILDIRIM, Dursun (1999), Türk Edebiyatında Bektaşi Fıkraları, Akçağ Yayınları, Ankara.

\section{ELEKTRONİK KAYNAKLAR}

http://bagbasikasabasi.blogcu.com/egiste-fikrasi, erişim tarihi: 05.06.2016.

http://www.cumhuriyetarsivi.com, erişim tarihi: 29.05.2016.

http://www.hadim.bel.tr, erişim tarihi: 25.06.2016.

http://www.hadimbagbasi.com.tr, 03.07.2016.

http://www.wikipedia.org.tr, 06.18.2016. 


\section{EKLER}

\section{Eğiste Fıkralarından Örnekler}

\section{Eğisteli Bekçi}

Eğiste ve Bolat, Konya'nın Hadim ilçesine bağlı iki komşu köydür. Her iki köyde de bağcllık önde gelen tarım faaliyetlerindendir. Buraların üzümü ve pekmezi meşhurdur.

Yaz aylarının sonuna doğru bölgede üzüm hasatı yapılmaktadır. Hasat mevsimi yaklaşınca bağlara hırsız dadanmaktadır. Özellikle Bolatlılar, bu hırsızlardan bıkıp usanmıştır. Bin bir emekle yetiştirdikleri üzümleri olgunlaşınca hırsızlar toplayıp götürmekte, köylünün elleri boş kalmaktadır. Bolatlılar, bir araya gelirler ve bu soruna bir çare aramaya başlarlar. Sonunda bağlarını beklemesi için bir bekçi tutmaya karar verirler. İşi gücü olmayan eli boş bir Eğisteliyi, cüzi bir maaş karşılığında bekçi olarak tutarlar.

Eğisteli bağları beklemeye başlar. Bolatlılar da üzümlerini bekleyen biri olduğu için rahata kavuşmuştur. Günler böylece geçip giderken Eğisteli bekçi bir gün bağların arasında bir hırsız yakalar. Yakaladığı hırsız da kendi köylüsüdür. Hırsızı biraz hırpaladıktan sonra bir ağacın dibine oturtup ayaklarını bağlar ve köylülere haber vermeye gider. Koşar adım Bolat'a ulaşır ve köylülere bir hırsız yakaladığını söyler. Köylüler sorar:

"Eee nirde yakaladığın hırsız?"

Bekçi, bağların orada bir ağacın dibine oturtup ayaklarını bağladığını söyler. Köylüler hırsızın ellerini bağlayıp bağlamadığını sorarlar. Bekçi, hırsızın sadece ayaklarını bağladığını söyler. Köylüler:

"Adamın ellerini bağlamamışsın ki ayaklarını çözüp çoktan gaçmıştır." derler.

Bekçi:

"Yav o da bizim köylü, benim aklıma gelmediyse onun aklına da gelmemiştir." der.

Hep birlikte gidip bakarlar. Eğisteli hırsız, cebinden tabakasını çıkarıp bir tütün sarmış onu tellendirmekte ve ayakları bağlı bir şekilde oturmaktadır. (Kaynak Kişi: Ahmet IŞIK, Hadim 1952, ilkokul mezunu, babasından öğrenmiş, 18 Aralık 2015)

\section{Kaya Ürkütmek}

Eğiste, sarp dağların arasına kurulmuş bir köydür. Vakt-i evvelde köyün tam üzerinde dağın tepesinde oldukça büyük bir kaya vardır. Eğisteliler oturup muhabbet ederlerken içlerinden birinin gözü bu kayaya takılır. Arkadaşlarına,

"Bu gaya ordan bir yuvarlanırısa bütün köyü alır götürür." der.

$\mathrm{Bu}$ durum hepsinde büyük bir endişeye sebep olur. Kafa kafaya verip o kayayı oradan kaldırmanın yollarını düşünürler. Hep birlikte dağın tepesine çıkıp kayayı yerinden kaldırmaya çalışlar ama güçleri yetmez.

İçlerinde en akıllı olanı:

"Siz gayayı aşşaya yuvarlayın. Ben de şurda ki ağacın ardına saklanayım. Gaya tam önümden geçerken birden garşısına çıkıp böh diyip ürküteyim, gorkup gaçsın gitsin." der.

Bu fikir hepsinin aklına yatar. Kaldıraç yardımıyla güç bela kayayı yerinden oynatırlar ve dağdan aşağıya yuvarlarlar. Bayır aşağı yuvarlanan kaya gittikçe hızlanır. Kaya tam ağacın yanından geçerken bizim Eğisteli, kayanın önüne atlar ve "böh" biye bağırır; ancak hızla gelen kayanın altında kalır ve kafası kopar.

Arkadaşları neticeyi görmek için dağdan aşağı koşar adım gelirler ve görürler ki arkadaşlarının kafası yok. Etrafı ararlar tararlar ancak adamın kafasını bulamazlar. Bu sefer aralarında tartışmaya başlarlar kafası vardı, yoktu diye. Her kafadan bir ses çıar. Sonunda karısına sormaya karar verirler. Adamın evine gelirler ve kadına kocasının kafası olup 
olmadığını sorarlar.

Kadın:

"Ayran içerken tasın içinde sakalı cöm cöm cömbüldeyip dururdu; amma gafası var mıydı, yok muydu hiç dikkat itmedim." der. (Kaynak Kişi: Hüseyin BEYHAN, Hadim 1984, üniversite mezunu, babaannesinden dinlemiş, 6 Mayıs 2016)

\section{Minare Tohumu}

Eğisteli bir adam İstanbul'a gezmeye gider. Gezip tozarken yolu Sultan Ahmet Camii'ne düşer. Caminin karşısına geçip hayranlıkla izlemeye başlar. Özellikle göğe uzanıp giden minareler dikkatini çekmiştir. Eğistelinin hayran hayran camiye baktığını gören uyanık bir Kayserili, yaklaşır ve

"Nereye bakiyorsun hemşerim?" der.

Eğisteli, minarelere baktı̆̆ını söyler.

“Nasil da büyümüşler öyle. Bunun tohumu bulunur mu?" der.

Karşısında saf birinin olduğunu anlayan Kayserili,

"Tohumu bende var ama pahalıdır." der.

Eğisteli, kesesinde ne kadar para varsa çıkarır, içinden bir yol parası alıp kalanını adama verir. Kayserili, minare tohumu diye havuç tohumunu Eğisteliye satar.

Tohumu alan Eğisteli, sevinç içinde köyünün yolunu tutar. Uygun bir yere tohumu eker. Gerekli bakımları yapar, sular, çapalar ancak uzunca bir süre geçmesine rağmen tohum göklere yükselmez. Aldatıldığını düşünen Eğisteli, tekrar İstanbul'a gider ve yine aynı yerde Kayseriliyi bulur, yakasına yapışır ve parasını ister. Kayserili:

"Hemşerim, sen o tohumu ters ekmişsindir; git köyüne kontrol et." der.

Eğisteli köyüne döner ve tohumu ektiği yeri kazar. Toprağın içine doğru uzanan havucu görünce,

"Gayserili doğru söylemiş ya la. Biz bunu ters ekmişiz." der. (Kaynak Kişi: Mehmet GÖKHAN, Hadim 1977, üniversite mezunu, babasından öğrenmiş, 20 Mart 2016)

\section{Saklambaç}

Konya'nın köylerinde kış, genellikle insanların vaktinin en bol olduğu, işin gücün pek olmadığı bir mevsimdir. Böyle bir kış gününde Eğistelilerin boş durmaktan canı sıkılır. Ne yapalım, ne edelim de vakit geçirelim diye düşünürlerken akıllarına saklambaç oynamak gelir. On-on beş kişi bir araya gelirler ve aralarından birini ebe seçerler. Ebe arkasını döner ve saymaya başlar:

"Bir, iki, üç... Önüm, arkam; sağım, solum; saklanmayan ebe, sobe..."

Herkes bir yerlere saklanır ancak içlerinden biri saklanacak yer bulamaz. Saklanacak bir yer aramak için önce oyunun oynandığı mahalleden, ardından köyden çıkar. O sırada yoldan geçmekte olan bir otobüse atlayıp Kaşınhanı'na kadar gelir. Köyden bir hayli uzakta, Kaşınhanı Köprüsü'nün altına saklanır ve beklemeye başlar. Uzunca bir müddet bekler ancak gelen giden, kendisini arayan bulan olmaz. Bazı rivayetlere göre köprünün altında üç gün bekler. Beklemekten sıkılan Eğisteli, kafasını köprüden çıkarır. O sırada köprüden geçmekte olan bir köylüsünü görür ve onunla köye haber salar,

"Gelip bulacaksa bulsun, yoksa ben bu oyunu bozacağım." der.

Adam köye döner, ebeye haber verecek, bir de görsün ebe de hâlâ gözleri yumuk,

"Oldu mu, oldu mu?" diye bağırır durur. (Kaynak Kişi: Hüseyin BEYHAN, Hadim 1984, üniversite mezunu, babaannesinden dinlemiş, 6 Mayıs 2016) 


\section{Tarlaya Tuz Ekmek}

Osmanlı Devleti zamanında ülke savaş hâlindedir ve ülkede büyük bir kıtlık yaşanmaktadır. Halk yiyecek sıkıntısı çekmektedir. Özellikle tuz ihtiyacı had safhadadır. "Tuzsuz aşın tadı olmaz." derler. Halk, tuz ihtiyacını karşılayabilmek için çeşitli çareler aramaktadır. Bütün Eğiste halkı bir araya gelir ve bu sıkıntıdan kurtulmanın yollarını aramaya başlarlar. Herkes bir fikir ortaya atar; ancak hiçbiri akla yatkın bulunmaz. Sonunda sivri akıllının biri, "Kimde ne gadar duz varısa getirsin!" der. Herkes evinde ne kadar tuz varsa getirir. Tam bir okka tuz toplanır. Sivri akıllının fikriyle tuzu boş bir tarlaya ekerler.

Uzunca bir zaman tuzun filizlenmesini, boy vermesini beklerler ancak tarlada hiçbir değişiklik görülmez. Bunun sebebini araştırmak için köyden birkaç kişi görevlendirilir. Uzun süren gözlemlerden sonra teşhis konulur. Tuzu sinekler yemektedir. Bundan kurtulmak için uzun süre sinekler kovalanır, ilaçlama yapılır ancak başarılı olunamaz.

Sonunda sinekleri vurmaya karar verirler. Bütün köy halkı ellerinde tüfeklerle sinek avına çıkar. Av sırasında bir sinek köylülerden birinin alnına konar. Alnına sinek konan adam hafif bir ıslıkla arkadaşına seslenir ve parmağı ile alnındaki sineği gösterir. Arkadaşı nişan alır ve tüfeği ateşler. Hem sineği hem de arkadaşını öldürmüştür. Sonra silah sesinden uçuşan sineklerin ardından,

Silahı ateşleyen köylü:

"Bir sizden, bir bizden; biz de olduk bir okka duzdan." der. (Kaynak Kişi: Mehmet YÜKSEL, Hadim 1932, ilkokul mezunu, babasından dinlemiş, 20 Mart 2016) 